\title{
A Survey of Workflow Scheduling Algorithms and Research Issues
}

\author{
Lovejit Singh \\ Computer Science and \\ Engineering \\ UIET, Panjab University \\ Chandigarh, India
}

\author{
Sarbjeet Singh \\ Computer Science and \\ Engineering \\ UIET, Panjab University \\ Chandigarh, India
}

\begin{abstract}
Cloud Computing refers to a paradigm whereby services are offered via internet using pay as you go model. Services are deployed in data centers and the pool of data centers is collectively referred to as "Cloud". Data centers make use of scheduling techniques to optimally allocate resources to various jobs. Different scenarios require different scheduling algorithms. The selection of a particular scheduling algorithm depends upon various factors like the parameter to be optimized (cost or time), quality of service to be provided and information available regarding various aspects of job. Workflow applications are the applications which require various sub-tasks to be executed in a particular fashion in order to complete the whole task. These tasks have parent child relationship. The parent task needs to be executed before its child task. Workflow scheduling algorithms are supposed to preserve dependency constraints implied by their nature and structure. Resources are allocated to various sub-tasks of the original task by keeping into account these constraints. In this paper, various workflow scheduling algorithms have been surveyed. Some algorithms have been found to optimize cost, some have been found to optimize time, some focuses on reliability, some focuses on availability, some focuses on energy efficiency, some focuses on load balancing or some focuses on a combination of these parameters. A lot of work has already been done in the area of workflow scheduling but still, we feel that there is a need and lot of scope in applying other optimization techniques, like intelligent water drops, to schedule workflow applications.
\end{abstract}

\section{Keywords}

Cloud computing, workflow applications, workflow scheduling algorithms, intelligent water drops based algorithm.

\section{INTRODUCTION}

Cloud Computing enables the procurement of large amount of computational resources on demand by employing pay-peruse model. It delivers computational resources with the help virtualization technology. It shows new way to store data and run applications. Instead of storing data and running application on an individual desktop computer, everything is hosted on the Cloud. It allows us to access all the documents and run applications from anywhere in the world via the Internet.

In a Cloud, there are four main entities viz. Cloud User, Broker, Virtual Machines and Physical Machines [1]. The cloud users are the actual consumers of services and can submit their service requests from anywhere in the world. A cloud data center consists of physical machines. Using virtualization technology, virtual machines are created on the top of physical machines. Broker acts as an intermediator between cloud users and cloud datacenters. It is responsible for allocating cloud resources to user's workflow applications. It assigns virtual machines to user's workflow applications by making use a scheduling algorithm and SLA (Service Level Agreements) which is a written and agreed document between service provider and cloud user. Figure 1 represents the role of a cloud broker in a cloud environment.



Fig. 1 Role of Broker in Cloud Scheduling

The scheduling algorithms provide benefit to both, the cloud user as well as the service provider. At one hand, scheduling algorithms can be designed in such a way that they satisfies the QoS (Quality of Service) constraints imposed by cloud users and on the other hand, they can be designed to perform load balancing among virtual machines which results into improvement of resource utilization at service provider's end.

The rest of the paper is structured as follow: The workflow scheduling is presented in section 2. The survey of important workflow scheduling algorithms is presented in section 3 . Research issues in the area of workflow scheduling are presented in section 4 and section 5 concludes the work carried out. 


\section{WORKFLOW SCHEDULING}

In workflow scheduling, different sub tasks of a bigger task are allocated resources in such a way that some pre-defined objective criteria is met. There are various problems in bioinformatics, astronomy and business enterprise [2] in which a set of sub tasks is executed in a particular sequence in order to carry out a bigger task. In general, a workflow application requires series of steps to be executed in a particular fashion. These steps have parent child relationship. The parent task should be executed before its child task. The parent task is linked to child task according to set of rules [3].

A workflow application is generally represented as a Directed Acyclic Graph (DAG) such as $\mathrm{G}(\mathrm{V}, \mathrm{E})$ where $\mathrm{V}$ is the number of tasks and $\mathrm{E}$ is the information regarding data dependencies among tasks. A task which does not have any parent task is called entry task and a task which does not have any child task is called an exit task.

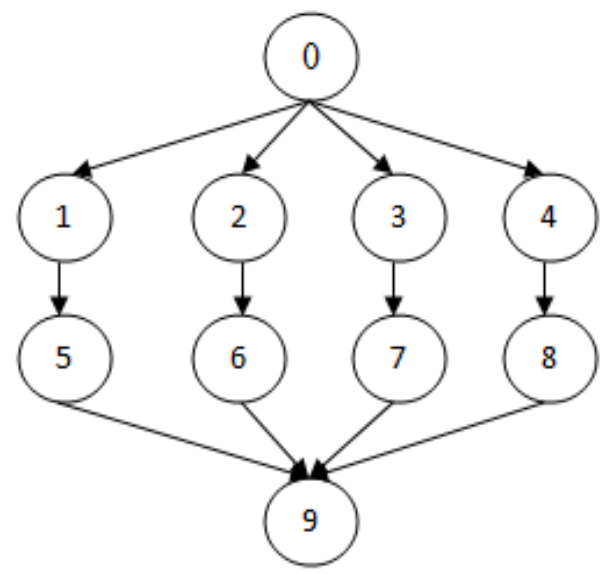

Fig. 2 A Workflow represented in the form of a graph

Figure 2 shows the dependencies among different tasks in a workflow graph $\mathrm{G}$. The parent task 0 is executed before child tasks 1, 2, 3 and 4.The output of parent node acts as an input

\begin{tabular}{|c|c|c|c|c|c|}
\hline $\begin{array}{l}\text { Authors and } \\
\text { Year }\end{array}$ & $\begin{array}{l}\text { Nature of } \\
\text { Scheduling } \\
\text { Algorithm }\end{array}$ & $\begin{array}{l}\text { Type of } \\
\text { Algorithm }\end{array}$ & $\begin{array}{l}\text { Objective } \\
\text { Criteria }\end{array}$ & Description & Environment \\
\hline $\begin{array}{l}\text { Rizos Sakellariou } \\
\text { and Henan Zhao } \\
\text { in } 2004 \text { [5] }\end{array}$ & Hybrid & Heuristic & Makespan & $\begin{array}{l}\text { A novel heuristic algorithm for DAG } \\
\text { scheduling on heterogeneous } \\
\text { machines, which break whole problem } \\
\text { to independent sub problems. It } \\
\text { performs better than DLS (Dynamic } \\
\text { List Scheduling), HEFT } \\
\text { (Heterogeneous Earliest Finish Time), } \\
\text { CPOP (Critical Path On a Processor), } \\
\text { FCP (Fastest Critical Path) and LMT } \\
\text { (Levelized-Min Time). }\end{array}$ & Grid \\
\hline $\begin{array}{l}\text { A. Mandal, K. } \\
\text { Kennedy, C. } \\
\text { Koelbel, G.Marin, } \\
\text { J. Crummy in } \\
2005 \text { [6] }\end{array}$ & $\begin{array}{c}\text { List } \\
\text { Scheduling }\end{array}$ & Heuristics & $\begin{array}{c}\text { Makespan, } \\
\text { Load Balance }\end{array}$ & $\begin{array}{l}\text { The heuristic based strategy is used to } \\
\text { schedule EMAN, a bio-imaging } \\
\text { workflow application. It results into } \\
1.5 \text { to } 2.2 \text { time better optimization of } \\
\text { makespan and load balance. }\end{array}$ & Grid \\
\hline $\begin{array}{l}\text { Markek } \\
\text { Wieczorek, Radu }\end{array}$ & Genetic, & $\begin{array}{l}\text { Heuristic } \\
\text { (HEFT, }\end{array}$ & Makespan & $\begin{array}{l}\text { In this paper the HEFT, Genetic and } \\
\text { Myopic algorithms were compared }\end{array}$ & Grid \\
\hline
\end{tabular}

to child node. The task 0 acts as entry node and task 9 act as an exit node. Task 9 is execute after the completion of tasks $5,6,7$ and 8 .

In workflow scheduling, the different tasks are allocated resources (e.g. virtual machines). The workflow scheduling decisions are taken by cloud broker, which works as an intermediator between the cloud user's workflow application and cloud provider's datacenters, as shown in Fig. 1. The scheduling algorithms are used by broker to find optimal map of workflow tasks and cloud resources (virtual machines). The role of workflow scheduling algorithm is to find the schedule which satisfies user's objectives. Users define their objectives in SLA (Service Level Agreement) document which is written between a cloud user and a cloud service provider. The user may require multiple objectives to be satisfied such as cost optimization, makespan optimization, reliability, deadline constrained, budget constrained etc. and it is the role of scheduling algorithm to find the optimal schedule which satisfies user's objectives.

\section{SURVEY OF WORKFLOW SCHEDULING ALGORITHMS}

Numbers of authors have done work in the area of workflow scheduling algorithms. Table 1 represents the description of work done in terms of type of scheduling algorithm, nature of scheduling algorithm, objective criteria i.e. the parameters which have been focused for optimization and the environment in which the scheduling algorithms were applied. The workflow scheduling algorithms can be heuristic or metaheuristic in nature [4]. The heuristic algorithms are priority based and mainly problem centric. The developer can use his own experience to assign priority to workflow applications and cloud resources. Meta-heuristic scheduling algorithms are the ones which do not need human interaction and provide general solution to workflow applications. These algorithms are applicable to wider range of workflow applications but the heuristic scheduling algorithms are fit for only specific applications [4] 


\begin{tabular}{|c|c|c|c|c|c|}
\hline $\begin{array}{l}\text { Prodan and } \\
\text { Thomas Fahringer } \\
\text { in } 2005 \text { [7] }\end{array}$ & HEFT, Myopic & $\begin{array}{l}\text { Myopic), } \\
\text { Meta- } \\
\text { Heuristic } \\
\text { (Genetic) }\end{array}$ & Optimization & $\begin{array}{l}\text { using balanced and unbalanced } \\
\text { workflows on the basis of execution } \\
\text { time. HEFT performs better as } \\
\text { compared with Myopic and Genetic. }\end{array}$ & \\
\hline $\begin{array}{l}\text { Jia Yu and Raj } \\
\text { Kumar Buyya in } \\
2006[8]\end{array}$ & Genetic & $\begin{array}{c}\text { Meta- } \\
\text { Heuristic }\end{array}$ & $\begin{array}{c}\text { Budget } \\
\text { Constrained }\end{array}$ & $\begin{array}{l}\text { Budget constrained genetic algorithm } \\
\text { is used to find the schedule that } \\
\text { minimizes the execution time while } \\
\text { meeting a specified user budget. }\end{array}$ & Grid \\
\hline $\begin{array}{l}\text { Jia Yu and Raj } \\
\text { Kumar Buyya in } \\
2006[9]\end{array}$ & Genetic & $\begin{array}{c}\text { Meta- } \\
\text { Heuristic }\end{array}$ & $\begin{array}{l}\text { Deadline and } \\
\text { Budget } \\
\text { Constrained }\end{array}$ & $\begin{array}{l}\text { Genetic algorithm was used to find the } \\
\text { schedule for workflow application that } \\
\text { meet the user defined budget and } \\
\text { deadline. }\end{array}$ & Grid \\
\hline $\begin{array}{l}\text { M. Rahman, S. } \\
\text { Venugopal and R. } \\
\text { Buyya in } 2007 \\
{[10]}\end{array}$ & $\begin{array}{l}\text { DCP (Dynamic } \\
\text { Critical Path) }\end{array}$ & Heuristic & $\begin{array}{c}\text { Resource } \\
\text { Availability }\end{array}$ & $\begin{array}{l}\text { DCP assign priority to a task in the } \\
\text { critical path. The priority based DCP } \\
\text { results better in performance as } \\
\text { compared with meta heuristic } \\
\text { algorithms where resource availability } \\
\text { changes frequently. }\end{array}$ & Grid \\
\hline $\begin{array}{l}\text { Wei Neng Chen, } \\
\text { Jun Zhang and } \\
\text { Yang Yu in } 2007 \\
{[11]}\end{array}$ & $\begin{array}{l}\text { Ant Colony } \\
\text { Optimization }\end{array}$ & $\begin{array}{c}\text { Meta- } \\
\text { Heuristic }\end{array}$ & $\begin{array}{l}\text { Deadline } \\
\text { Constrained, } \\
\text { Cost } \\
\text { Minimization }\end{array}$ & $\begin{array}{l}\text { ACO was used to schedule workflow } \\
\text { application. It finds the schedule that } \\
\text { satisfies user defined deadline and } \\
\text { minimize the cost of execution of } \\
\text { workflow application. }\end{array}$ & Grid \\
\hline $\begin{array}{l}\text { Bogdan Simion, } \\
\text { Catalin } \\
\text { Leordeanu, Florin } \\
\text { Pop and Valentin } \\
\text { Cristea in } 2007 \\
{[12]}\end{array}$ & Hybrid & Heuristic & $\begin{array}{c}\text { Makespan } \\
\text { and Load } \\
\text { Balance }\end{array}$ & $\begin{array}{l}\text { Improved Critical Path using } \\
\text { Descendant Prediction (ICPDP) } \\
\text { algorithm has quadratic polynomial } \\
\text { time complexity. It finds the schedule } \\
\text { that results in makespan minimization } \\
\text { and improve the utilization of } \\
\text { resources. }\end{array}$ & Grid \\
\hline $\begin{array}{lr}\text { Fli } & \text { Tao, } \\
\text { Dongming } \text { Zhao, } \\
\text { Yefa Hu and } \\
\text { Zude Zhou in } \\
2008[13]\end{array}$ & $\begin{array}{c}\text { Particle Swarm } \\
\text { Optimization }\end{array}$ & $\begin{array}{c}\text { Meta- } \\
\text { Heuristic }\end{array}$ & $\begin{array}{l}\text { Makespan, } \\
\text { Cost and } \\
\text { Reliability }\end{array}$ & $\begin{array}{l}\text { Multi-objective MGrid resource } \\
\text { service composition and optimal- } \\
\text { selection (MO-MRSCOS) problem is } \\
\text { solved by PSO. It minimizes execution } \\
\text { time, cost, and maximize the } \\
\text { reliability. }\end{array}$ & Grid \\
\hline $\begin{array}{l}\text { A.K.M Khaled } \\
\text { Ahsan Talukder, } \\
\text { Michael Kirley } \\
\text { and Raj Kumar } \\
\text { Buyya in } 2009 \\
\text { [14] }\end{array}$ & Genetic & $\begin{array}{c}\text { Meta- } \\
\text { Heuristic }\end{array}$ & $\begin{array}{l}\text { Makespan } \\
\text { and Cost } \\
\text { Optimization }\end{array}$ & $\begin{array}{l}\text { Multi-Objective Differential Evolution } \\
\text { (MODE) that optimize both cost and } \\
\text { makespan for workflow application. } \\
\text { The results of MODE show better } \\
\text { performance than PAES (Pareto- } \\
\text { archived Evolutionary Strategy). }\end{array}$ & Grid \\
\hline $\begin{array}{l}\text { Wei Neng Chen } \\
\text { and Jun Zhang in } \\
2009[15]\end{array}$ & $\begin{array}{l}\text { Ant Colony } \\
\text { Optimization }\end{array}$ & $\begin{array}{c}\text { Meta- } \\
\text { Heuristic }\end{array}$ & $\begin{array}{l}\text { Deadline, } \\
\text { Budget, } \\
\text { Makespan, } \\
\text { Cost and } \\
\text { Reliability }\end{array}$ & $\begin{array}{l}\text { ACO finds the schedule that meets all } \\
\text { user imposed QoS constraints. It } \\
\text { calculates the pheromone values based } \\
\text { on heuristics and experiments are done } \\
\text { on ten workflow applications. }\end{array}$ & Grid \\
\hline $\begin{array}{l}\text { Qian Tao, Hui } \\
\text { You Chang, Yang } \\
\text { Yi and Chunqin } \\
\text { Gu in } 2009 \text { [16] }\end{array}$ & $\begin{array}{c}\text { Particle Swarm } \\
\text { Optimization }\end{array}$ & $\begin{array}{c}\text { Meta- } \\
\text { Heuristic }\end{array}$ & $\begin{array}{l}\text { Makespan, } \\
\text { Cost and } \\
\text { Load Balance }\end{array}$ & $\begin{array}{l}\text { Rotary Hybrid Discrete Particle Swarm } \\
\text { Optimization (RHDPSO) algorithm } \\
\text { that optimize the makespan, cost and } \\
\text { perform load balancing when } \\
\text { scheduling workflow application. The } \\
\text { simulation results show that the } \\
\text { RHDPSO algorithm has fast } \\
\text { convergence, high precision and strong } \\
\text { robustness as compared with DPSO. }\end{array}$ & Grid \\
\hline
\end{tabular}




\begin{tabular}{|c|c|c|c|c|c|}
\hline $\begin{array}{l}\text { Yanli Hu, Lining } \\
\text { Xing, Weiming } \\
\text { Zhang, Weidong } \\
\text { Xiao and Daquan } \\
\text { Tang in } 2010 \text { [17] }\end{array}$ & $\begin{array}{c}\text { Ant Colony } \\
\text { Optimization }\end{array}$ & $\begin{array}{c}\text { Meta- } \\
\text { Heuristic }\end{array}$ & $\begin{array}{l}\text { Deadline and } \\
\text { Budget } \\
\text { Constrained }\end{array}$ & $\begin{array}{l}\text { Knowledge based ant colony } \\
\text { optimization algorithm which find the } \\
\text { schedule that minimizes execution cost } \\
\text { while meeting the user deadlines.. }\end{array}$ & Grid \\
\hline $\begin{array}{l}\text { Suraj Panday, } \\
\text { Linlin Wu, } \\
\text { Siddeshwara } \\
\text { Mayura Guru and } \\
\text { Raj Kumar Buyya } \\
\text { in 2010 [18] }\end{array}$ & $\begin{array}{c}\text { Particle Swarm } \\
\text { Optimization }\end{array}$ & $\begin{array}{c}\text { Meta- } \\
\text { Heuristic }\end{array}$ & $\begin{array}{c}\text { Cost } \\
\text { Optimization }\end{array}$ & $\begin{array}{l}\text { PSO algorithm that allocates Cloud } \\
\text { resources to workflow application. It } \\
\text { consider both computation cost and } \\
\text { data transmission cost when finding } \\
\text { schedule. PSO achieves } 3 \text { times cost } \\
\text { saving as compared with BRS (Best } \\
\text { Resource Selection). }\end{array}$ & Cloud \\
\hline $\begin{array}{l}\text { Zhangjum } \mathrm{Wu}, \\
\text { Zhiwei } \\
\text { Lichuan } \mathrm{Nu} \text { and } \\
\text { Xiao Liu in } 2010 \\
{[19]}\end{array}$ & $\begin{array}{c}\text { Particle Swarm } \\
\text { Optimization }\end{array}$ & $\begin{array}{c}\text { Meta- } \\
\text { Heuristic }\end{array}$ & $\begin{array}{l}\text { Makespan } \\
\text { and } \\
\text { Cost } \\
\text { Optimization }\end{array}$ & $\begin{array}{l}\text { Revised Discrete Particle Swarm } \\
\text { Optimization (RDPSO) algorithm } \\
\text { minimize the makespan and cost as } \\
\text { compared with standard PSO and BRS. }\end{array}$ & Cloud \\
\hline $\begin{array}{l}\text { Yong Wang, R. } \\
\text { M. Bahati and M. } \\
\text { A. Bauer in } 2011 \\
\text { [20] }\end{array}$ & $\begin{array}{l}\text { Novel DBC } \\
\text { (Deadline and } \\
\text { Budget } \\
\text { Constrained) }\end{array}$ & Heuristic & $\begin{array}{l}\text { Deadline and } \\
\text { Budget } \\
\text { Constrained }\end{array}$ & $\begin{array}{l}\text { Novel DCP is compared with DCP in } \\
\text { GridSim simulator. The experiment } \\
\text { results show that the workflow } \\
\text { completion ratios of Novel DCP are } \\
\text { higher than DCP. }\end{array}$ & Grid \\
\hline $\begin{array}{l}\text { Sawant and } \\
\text { Shailesh in } 2011 \\
{[21]}\end{array}$ & Genetic & $\begin{array}{c}\text { Meta- } \\
\text { Heuristic }\end{array}$ & Load Balance & $\begin{array}{l}\text { Genetic algorithm uses historical data } \\
\text { and current state of the system to } \\
\text { ensure better load balancing and } \\
\text { reduce the number of dynamic VM } \\
\text { migration. }\end{array}$ & Cloud \\
\hline $\begin{array}{l}\text { F. Coutinho L. A. } \\
\text { V. Decarvalho } \\
\text { and R. Santana in } \\
2011 \text { [22] }\end{array}$ & HGreen & Heuristic & $\begin{array}{c}\text { Energy } \\
\text { Efficient }\end{array}$ & $\begin{array}{l}\text { H-Green heuristic algorithm schedules } \\
\text { the heavier tasks on maximum green } \\
\text { resources. The simulation results have } \\
\text { shown that the H-Green algorithm } \\
\text { reduce the power consumption in } \\
\text { global grids }\end{array}$ & Grid \\
\hline $\begin{array}{l}\text { Xiaofeng Wang, } \\
\text { Chee Shin Yeo, } \\
\text { Jinshu Su and Raj } \\
\text { kumar Buyya in } \\
2011[23]\end{array}$ & Genetic & $\begin{array}{c}\text { Meta- } \\
\text { Heuristic }\end{array}$ & $\begin{array}{l}\text { Makespan, } \\
\text { Reliability }\end{array}$ & $\begin{array}{l}\text { RD (Reliability Driven) reputation is } \\
\text { implemented to evaluate the reliability } \\
\text { of resource in widely distributed } \\
\text { systems. The look ahead genetic } \\
\text { algorithm (LAGA) that utilize the RD } \\
\text { reputation to optimize both makespan } \\
\text { and reliability for workflow } \\
\text { application. }\end{array}$ & Cloud \\
\hline $\begin{array}{l}\text { Eugen Feller, } \\
\text { Louis Rilling and } \\
\text { Christine Morin } \\
\text { in } 2011[24]\end{array}$ & $\begin{array}{l}\text { Ant Colony } \\
\text { Optimization }\end{array}$ & $\begin{array}{c}\text { Meta- } \\
\text { Heuristic }\end{array}$ & $\begin{array}{c}\text { Energy } \\
\text { Efficient }\end{array}$ & $\begin{array}{l}\text { ACO achieves better server utilization } \\
\text { and requires fewer machines for } \\
\text { scheduling workflow application as } \\
\text { compared with greedy algorithm. }\end{array}$ & Cloud \\
\hline $\begin{array}{l}\text { Rajarathinam } \\
\text { Jeyarani, } \mathrm{N} . \\
\text { Nagaveni and } \\
\text { Vasanth Ram in } \\
2011[25]\end{array}$ & $\begin{array}{l}\text { Particle Swarm } \\
\text { Optimization }\end{array}$ & $\begin{array}{c}\text { Meta- } \\
\text { Heuristic }\end{array}$ & $\begin{array}{c}\text { Energy } \\
\text { Efficient }\end{array}$ & $\begin{array}{l}\text { Self-adaptive PSO algorithm is used to } \\
\text { optimally placement of VM (Virtual } \\
\text { Machine) in Cloud. Simulation results } \\
\text { shows that SAPSO outperforms and } \\
\text { power aware VM provisioning in large } \\
\text { scale, heterogeneous and dynamic } \\
\text { Cloud environment as compared with } \\
\text { Multi-Strategy Ensemble PSO. }\end{array}$ & Cloud \\
\hline $\begin{array}{lr}\text { Saurabh } & \text { Kumar } \\
\text { Garg, } & \text { Parmod } \\
\text { Kongurthi } & \text { and } \\
\text { Raj Kumar Buyya }\end{array}$ & Hybrid & $\begin{array}{c}\text { Meta- } \\
\text { Heuristic }\end{array}$ & $\begin{array}{c}\text { Cost } \\
\text { Optimization }\end{array}$ & $\begin{array}{l}\text { Linear programming driven genetic } \\
\text { algorithm that minimizes the cost of all } \\
\text { users in coordinated manner with } \\
\text { negligible time overhead. }\end{array}$ & Grid \\
\hline
\end{tabular}




\begin{tabular}{|c|c|c|c|c|c|}
\hline in 2011 [26] & & & & & \\
\hline $\begin{array}{l}\text { Jiandun Li, Junjie } \\
\text { Peng, Zhou Lei } \\
\text { and Wu Zhang in } \\
2011[27]\end{array}$ & Hybrid & $\begin{array}{c}\text { Meta- } \\
\text { Heuristic }\end{array}$ & $\begin{array}{c}\text { Energy } \\
\text { Efficient and } \\
\text { Load Balance }\end{array}$ & $\begin{array}{l}\text { Hybrid scheduling approach was used } \\
\text { to schedule workflow application in } \\
\text { private clouds. Simulation results show } \\
\text { that it can save more time for users, } \\
\text { conserve more energy and achieve } \\
\text { higher level of load balancing }\end{array}$ & Cloud \\
\hline $\begin{array}{l}\text { H. M Fard, R. } \\
\text { Prodan, J. J. D } \\
\text { Barrionuevo and } \\
\text { T. Fahringer in } \\
2012[28]\end{array}$ & $\begin{array}{c}\text { List } \\
\text { Scheduling }\end{array}$ & Heuristic & $\begin{array}{l}\text { Makespan, } \\
\text { Economic } \\
\text { Cost, Energy } \\
\text { Consumption, } \\
\text { Reliability }\end{array}$ & $\begin{array}{l}\text { The scheduling algorithm is } \\
\text { implemented in ASKALON } \\
\text { environment for Grid and Cloud } \\
\text { Computing. It outperform as compared } \\
\text { with bi-criteria heuristic and bi-criteria } \\
\text { genetic algorithm. }\end{array}$ & $\begin{array}{c}\text { Grid and } \\
\text { Cloud }\end{array}$ \\
\hline $\begin{array}{l}\text { Timur } \\
\text { Keskinturk, } \\
\text { Mehmet B. } \\
\text { Yildirim and } \\
\text { Mehmet Barut in } \\
2012 \text { [29] }\end{array}$ & $\begin{array}{c}\text { Ant Colony } \\
\text { Optimization }\end{array}$ & $\begin{array}{c}\text { Meta- } \\
\text { Heuristic }\end{array}$ & Load Balance & $\begin{array}{l}\text { ACO minimize average relative } \\
\text { percentage of imbalance (ARPI) with } \\
\text { sequence dependent setup times in a } \\
\text { parallel machine environment. } \\
\text { Simulation results show that ACO } \\
\text { perform better load balancing than } \\
\text { heuristic and genetic algorithm. }\end{array}$ & Cloud \\
\hline $\begin{array}{l}\text { S. H. Niu, S. K. } \\
\text { Ong and A.Y. C } \\
\text { Nee in } 2012 \text { [30] }\end{array}$ & $\begin{array}{c}\text { Intelligent } \\
\text { Water Drops } \\
\text { (IWD) }\end{array}$ & $\begin{array}{c}\text { Meta- } \\
\text { Heuristic }\end{array}$ & $\begin{array}{c}\text { Makespan } \\
\text { Optimization }\end{array}$ & $\begin{array}{l}\text { IWD algorithm was used to solve job } \\
\text { shop scheduling problem in Cloud. } \\
\text { The IWD employ five schemes to } \\
\text { increase the diversity of the solution } \\
\text { space as well as the solution quality. }\end{array}$ & Cloud \\
\hline $\begin{array}{l}\text { Salid Abrishami, } \\
\text { Mahmoud } \\
\text { Naghibzadeh and } \\
\text { Dick H. J. E pema } \\
\text { in } 2013 \text { [31] }\end{array}$ & $\begin{array}{l}\text { PCP (Partial } \\
\text { Critical Path) }\end{array}$ & Heuristic & $\begin{array}{c}\text { Deadline- } \\
\text { Constraint, } \\
\text { Cost } \\
\text { Minimization }\end{array}$ & $\begin{array}{l}\text { PCP algorithm minimizes the } \\
\text { execution time while meeting the user } \\
\text { defined deadline. Two types of PCP is } \\
\text { implemented in Cloud i.e. IC-PCP } \\
\text { (IaaS Cloud Partial Critical Path) and } \\
\text { IC-PCPD2 (IaaS Cloud Partial Critical } \\
\text { Path with Deadline Distribution). The } \\
\text { simulation results show that IC-PCP } \\
\text { performs better than IC-PCPD2. }\end{array}$ & Cloud \\
\hline $\begin{array}{l}\text { Zhangjun Wu, } \\
\text { Xiao Liu, Zhiwei } \\
\text { Ni, Dong Yuan } \\
\text { and Yun Yang in } \\
2013 \text { [32] }\end{array}$ & $\begin{array}{l}\text { Genetic, Ant } \\
\text { Colony } \\
\text { Optimization } \\
\text { and particle } \\
\text { swarm } \\
\text { Optimization }\end{array}$ & $\begin{array}{c}\text { Meta- } \\
\text { Heuristic }\end{array}$ & $\begin{array}{l}\text { Makespan, } \\
\text { Cost and } \\
\text { Resource } \\
\text { Utilization }\end{array}$ & $\begin{array}{l}\text { GA, ACO and PSO were implemented } \\
\text { to solve the issue of market-oriented } \\
\text { hierarchical scheduling strategy in } \\
\text { Cloud workflow systems. ACO } \\
\text { perform better than other scheduling } \\
\text { strategies }\end{array}$ & Cloud \\
\hline $\begin{array}{l}\text { S. Kaur and S. } \\
\text { Singh [33] }\end{array}$ & PSO and others & $\begin{array}{c}\text { Meta- } \\
\text { Heuristic } \\
\text { and others }\end{array}$ & $\begin{array}{l}\text { Constraint- } \\
\text { based }\end{array}$ & $\begin{array}{l}\text { Grouping the jobs according to } \\
\text { processing capabilities of available } \\
\text { resources results in better throughput, } \\
\text { resource utilization and low } \\
\text { communication time. }\end{array}$ & Grid \\
\hline
\end{tabular}

Table 1: A brief description and comparison among various workflow scheduling algorithms 


\section{RESEARCH}

\section{CHALLENGES}

\section{SCHEDULING ALGORITHMS}

Workflow scheduling in a cloud environment is a challenging task because of the following reasons:

- The resource pool is central which caters to the needs of all the jobs. So it is difficult to predict which resources will be available at the time of actual execution of the jobs.

- It is difficult to apply access control enforcement while the workflow is being executed, if the access rights of jobs change dynamically.

- It is difficult to handle the dynamic workflow applications in which the structure of workflow graph changes with time.

- It is difficult to reduce overhead involved while generating schedules for multiple workflows because there can be many users competing for common resources and decisions must be made in possible shortest time.

- It is difficult to achieve maximum possible utilization of resources while scheduling levelized workflow applications because of dependencies, and different load and resource requirements among different levels.

- The scheduling decisions for workflow applications become complicated when made by multiple distributed schedulers in hybrid Cloud.

- The virtual instances run on physical machines. When physical machine fails due to hardware failure or any other reason, the entire workflow application may need to be restarted. It is difficult to migrate one workflow application running on one virtual machine to another virtual machine.

- It is difficult to achieve multi-objective criteria imposed by certain workflow applications. Different techniques produce different results in such situations and it becomes difficult to select a particular scheduling technique for a generalized class of applications.
All the points mentioned above make workflow scheduling a complex and challenging task. Each of the challenge mentioned above require new techniques, new methodologies and new models or frameworks to effectively address that challenge.

Besides this, six workflow scheduling algorithms viz. List Heuristic, Genetic, Ant Colony Optimization, Particle Swarm Optimization, Hybrid and Intelligent Water Drops scheduling algorithms have also been studied. We felt that there is a need to explore Intelligent Water Drops based scheduling algorithm for workflow applications. The IWD may results into better performance than existing workflow scheduling algorithms. Very less work has been done in exploring intelligent water drops based algorithm for scheduling workflow applications. Table 2 shows the work which require further attention as well as the work which has already been attempted by different researchers in the area of workflow scheduling. Two signs have been used in Table 2. Following is a brief description of these signs:

$\checkmark \quad$ : Tick sign means that work has already been done in that area and there is a workflow scheduling algorithm for solving that type of problem.

? : Question mark sign means that there is a need to explore workflow scheduling algorithm for that particular domain focusing on different aspects like cost optimization, deadline constrained, budget constrained, reliability, load balance, availability and energy efficient.

For example, tick signs exits under makespan in intelligent water drop algorithm row shows that there is an IWD based algorithm that optimizes makespan for workflow applications. Question mark sign under other columns of IWD row means that there is a need to explore those aspects i.e. cost, deadline and budget constrained, reliability, load balance, availability and energy efficient using IWD to schedule workflow applications.

\begin{tabular}{|l|l|l|l|l|l|l|l|l|}
\hline $\begin{array}{c}\text { Sched Constraints } \\
\text { Algorithms }\end{array}$ & $\begin{array}{l}\text { Make } \\
\text { span }\end{array}$ & Cost & $\begin{array}{l}\text { Deadline } \\
\text { Constrained }\end{array}$ & $\begin{array}{l}\text { Budget } \\
\text { Constrained }\end{array}$ & Reliability & $\begin{array}{l}\text { Load } \\
\text { Balance }\end{array}$ & Availability & $\begin{array}{l}\text { Energy } \\
\text { Efficient }\end{array}$ \\
\hline List Heuristic & $\checkmark$ & $\checkmark$ & $\checkmark$ & $\checkmark$ & $\checkmark$ & $\checkmark$ & $\checkmark$ & $\checkmark$ \\
\hline Genetic & $\checkmark$ & $\checkmark$ & $\checkmark$ & $\checkmark$ & $\checkmark$ & $\checkmark$ & $\checkmark$ & $?$ \\
\hline $\begin{array}{l}\text { Ant Colony } \\
\text { Optimization }\end{array}$ & $\checkmark$ & $\checkmark$ & $\checkmark$ & $\checkmark$ & $\checkmark$ & $\checkmark$ & $?$ & $\checkmark$ \\
\hline $\begin{array}{l}\text { Particle Swarm } \\
\text { Optimization }\end{array}$ & $\checkmark$ & $\checkmark$ & $\checkmark$ & $\checkmark$ & $?$ & $\checkmark$ & $?$ & $\checkmark$ \\
\hline $\begin{array}{l}\text { Hybrid } \\
\text { Intelligent } \\
\text { Water Drop }\end{array}$ & $\checkmark$ & $\checkmark$ & $\checkmark$ & $\checkmark$ & $?$ & $\checkmark$ & $?$ & $\checkmark$ \\
\hline
\end{tabular}

Table 2: Table showing different areas which require further attention and the areas which have already been explored 


\section{CONCLUSIONS}

In this paper, we surveyed various existing workflow scheduling algorithms and tabulated them on the basis of nature of scheduling algorithm, type of algorithm, objective criteria and the environment to which the workflow scheduling algorithm was applied. From the literature reviewed, it is clear that lot of work has already been in the area of workflow scheduling but still there are many areas which require further attention e.g. there is a need to explore energy efficient genetic algorithm for workflow application whereas cost and deadline constraints have already been addressed using genetic algorithms. These areas have been marked in Table 2. We also conclude that there is a need to explore intelligent water drops based algorithm for workflow scheduling applications.

\section{REFERENCES}

[1] Rajkumar Buyya, Chee Shin Yeo, Srikumar Venugopal, James Broberg, and Ivona Brandic. 2009. Cloud Computing and Emerging IT Platforms: Vision, Hype, and Reality for Delivering Computing as the 5th Utility. Journal Future Generation Computer Systems Archive, vol. 25, pp. 599-616, Elsevier Science Publisher.

[2] Y. Du and X. Li. 2008.Application of Workflow Technology to Current Dispatching Order System. International Journal of Computer Science and Network Security, 8(3), 59-61.

[3] R. Allen. 2001. Workflow: an Introduction Workflow Management Coalition, Workflow Handbook.

[4] Jia Yu, Raj Kumar Buyya and Kotagiri Ramamohanarao. 2008. Workflow Scheduling Algorithm for Grid Computing. Meta-heuristics for Scheduling in Distributed Computing Environment, Vol. 146, Pg. 173214, Springer Berlin Heidelberg.

[5] Rizos Sakellariou and Henan Zhao. 2004. Hybrid Heuristic for DAG Scheduling on Heterogeneous Systems. Parallel and Distributed Processing Symposium, $18^{\text {th }}$ IEEE International Conference.

[6] A. Mandal, K. Kennedy, C. Koelbel, G. Marin, J. Crummey and B. Liu. 2005. Scheduling Strategies for Mapping Application Workflows onto the Grid. High Performance Distributed Computing, $14^{\text {th }}$ IEEE International Conference.

[7] Marek Wieczorek, Radu Prodan and Thomas Fahringer. 2005. Scheduling of Scientific Workflows in the ASKALON Grid Environment. ACM SIGMOD, Vol. 34, Issue 3, Pg. 56-62.

[8] Jia Yu and Raj Kumar Buyya. 2006. A Budget Constrained Scheduling of Workflow Applications on Utility Grids using Genetic Algorithms. Workflows in Support of Large-Scale Science, IEEE Conference, Pg. $1-10$.

[9] Jai YU and Raj Kumar Buyya. 2006. Scheduling Scientific Workflow Applications with Deadline and Budget Constraints using Genetic Algorithms. Scientific Programming Journal, Pg. 217-230, Vol. 14, Issue 3-4.

[10] M. Rahman, S. Venugopal and R. Buyya. 2007. A Dynamic Critical Path Algorithm for Scheduling Scientific Workflow Applications on Global Grids. EScience and Grid Computing, IEEE International Conference, Pg. 35-42.
[11] Wei Neng Chen, Jun Zhang and Yang Yu. 2007. Workflow Scheduling in Grids: an ant colony optimization approach. Evolutionary Computation, IEEE Conference, Pg. 3308-3315.

[12] Bogdan Simion, Catalin Leordeanu, Florin Pop and Valentin Cristea. 2007. A Hybrid Algorithm for Scheduling Workflow Applications in Grid Environments. OTM Confederated International Conferences, Pg. 1331-1348, Springer Berlin Heidelberg.

[13] Fli Tao, Dongming Zhao, Yefa Hu and Zude Zhou. 2008. Resource Service Composition and Its Optimal Selection Based on Particle Swarm Optimization in Manufacturing Grid System. Industrial Informatics, IEEE Transactions, Pg. 315-327.

[14] A. K. M Khaled , Michael Kirley and Raj Kumar Buyya. 2009. Multi-Objective Differential Evolution for Scheduling Workflow Applications on Global Grids. Journal Concurrency and Computation: Practice and Experience, Vol. 21, Issue 13.

[15] Wei Neng Chena and Jun Zhang. 2009. An Ant Colony Optimization Approach to a Grid Workflow Scheduling Problem with Various QoS Requirements. System, Man and Cybernetics, Applications and Reviews, IEEE Transactions, Vol. 39, Issue 1, Pg. 29-43.

[16] Qian Tao, Hui You Chang, Yang Yi, Chunqin Gu and Yang Yu. 2009. QoS Constrained Grid Workflow Scheduling Optimization Based on a Novel PSO Algorithm, Grid and Cooperative Computing. $8^{\text {th }}$ IEEE International Conference, Pg. 153-159.

[17] Yanli Hu, Lining Xing, Weiming Zhang, Weidong Xiao and Daquan Tang. 2010. A Knowledge Based Ant Colony Optimization for a Grid Workflow Scheduling Problem. First International Conference Beijing, China, Pg. 241-248, Springer Berlin Heidelberg.

[18] Suraj Pandy, Linlin Wu, Siddeshwara Mayura Guru and Raj Kumar Buyya. 2010. A Particle Swarm Optimization-Based Heuristic for Scheduling Workflow Application in Cloud Computing Environments. Advance Information Networking and Applications, IEEE International Conference, Pg. 400-407.

[19] Zhangjun $\mathrm{Wu}$, Zhiwei Ni, Lichuan Gu and Xiao Liu. 2010. A Revised Discrete Particle Swarm Optimization for Cloud Workflow Scheduling. Computational Intelligence and Security IEEE International Conference, Pg. 184-188.

[20] Yong Wang, R. M. Bhati and M. A. Bauer. 2011. A Novel Deadline and Budget Constrained Scheduling Heuristic for Computation Grids. Journal of Central South University of Technology Vol. 18, Issue 2, Pg. 465-472.

[21] Sawant Shailesh. 2011. A Genetic Algorithm Scheduling Approach for Virtual Machine Resource in a Cloud Computing Environment. Master's Project.

[22] F. Coutinho, L. A. V. Decarvalho and R. Santana. 2011. A Workflow Scheduling Algorithm for Optimizing Energy Efficient Grid Resources Usage, Dependable. Automic and Secure Computing, $9^{\text {th }}$ IEEE International Conference, Pg. 642-649. 
[23] Xiaofeng Wang, Chee Shin Yeo, Raj Kumar Buyya and Jinshu Su. 2011. Optimizing the Makespan and Reliability for Workflow Applications with Reputation and a Look-ahead Genetic Algorithm. Journal Future Generation Computer Systems, Vol. 27, Issue 8, Pg. 1124-1134.

[24] Eugen Feller, Louis Rilling and Christine Morin. 2011. Energy-Aware Ant Colony Based Workload Placement in Clouds, Grid Computing. $12^{\text {th }}$ IEEE International Conference, Pg. 26-33.

[25] Rajarathinam Jeyarani, N. Nagaveni and Vasanth Ram. 2011. Self Adaptive Particle Swarm Optimization for Efficient Virtual Machine Provisioning in Cloud. International Journal of Intelligent Information Technologies, Vol. 7, Issue 2.

[26] Saurabh Kumar Garg, Parmod Konugurthi and Raj Kumar Buyya. 2011. A Linear Programming Driven Genetic Algorithm for Meta-Scheduling on Utility Grids. International Journal of Parallel, Emergent and Distributed Systems, Vol. 26, Issue 6.

[27] Jiandun Li, Junjie Peng, Zhou Lei and Wu Zhang. 2011. An Energy Efficient Scheduling Approach Based on Private Clouds. Journal of Information and Computational Science, Pg. 716-724.

[28] H. M. Fard, R. Prodan, J. J. D Barrionuevo and T. Fahringer. 2012. A Multi-Objective Approach for Workflow Scheduling in Heterogeneous Environment.
Cluster, Cloud and Grid Computing $12^{\text {th }}$ IEEE International Conference, Pg. 300-309.

[29] Timur Keskinturk, Mehmet B. Yildirim and Mehmet Barut. 2012. An Ant Colony Optimization Algorithm for Load Balancing in Parallel Machines with SequenceDependent Setup Times. Computer and Operations Research, Vol. 39, Issue 6, Pg. 1225-1235.

[30] S. H. Niu, S. K. Ong and A. Y. C Nee. 2012. An Improved Intelligent Water Drops Algorithm for Achieving Optimal Job Shop Scheduling Solution. International Journal of Production Research, Vol. 50, Issue 15.

[31] Saeid Abrishami, Mahmoud Naghibzadeh and Dick H. J. E Pema. 2013. Deadline-Constrained Workflow Scheduling Algorithm for Infrastructure as a Service. Journal Future Generation Computer Systems, Vol. 29, Issue 1, Pg. 158-169.

[32] Zhangjun Wu, Xiao Liu, Zhiwei Ni Dong Yuan and Yun Yang. 2013. A Market Oriented Hierarchical Scheduling Strategy in Cloud Workflow Systems. The Journal of Super Computing, Vol. 63, Issue 1, Pg. 256-293, Springer US.

[33] Simrat Kaur and Sarbjeet Singh. 2012. Comparative Analysis of Job Grouping Based Scheduling Strategies in Grid Computing. International Journal of Computer Applications, Vol. 43, Issue 15. 